\title{
Ler Camões com Eduardo Lourenço ou Camões No FUTURO COM PAUlo dA Gama E OUTRAS AMOROSAS COMPANHIAS
}

\section{Reading Camões with Eduardo Lourenço or Camões in the future with Paulo da Gama and other amorous companies}

\author{
Luis Maffei*
}

\section{RESUMO}

Eduardo Lourenço é um dos grandes leitores da cultura e da literatura portuguesa. Ler Camões com a companhia e o auxílio do mestre é, mesmo aquando de divergência, enxergar a tarefa camoniana com olhos mais atentos. Este texto transita por diversos sentidos d'Os Lusíadas, especialmente pela presença dos irmãos Gama, metafórica e aberta à contradição, e por alguns dos desvios que o poema funda, tendo personagens como Baco na condição de protagonismo crítico.

Palavras-chave: Eduardo Lourenço; Camões; Os Lusíadas.

* $\quad$ Universidade Federal Fluminense. 


\begin{abstract}
Eduardo Lourenço is one of the greatest readers of Portuguese culture and literature. To read Camões with professor's company is, even when divergence occurs, an opportunity to see camonian task with even more attentive eyes. This text moves itself through several meanings of Os Lusiadas, especially through the presence of the Gama brothers, metaphoric and open to contradiction, and through some of the detours in which the poem is based, having characters like Baco as critical protagonists.
\end{abstract}

Keywords: Eduardo Lourenço; Camões; Os Lusíadas

Não sou assim muito fetichista. Mas por razões especiais tenho uma edição dos "Lusíadas" que é uma miniatura daquela edição famosa que saiu no início do século XIX em Paris, do Morgado de Mateus. E uma outra da "Divina Comédia", também de bolso. Costumo trazer sempre os "Lusíadas" comigo" (Eduardo Lourenço, "Quando venho a Portugal trago sempre comigo os 'Lusíadas'”, entrevista por Maria Ramos Silva, jornal i, Lisboa, 26/V/2012, p. 38)

"Camões no presente" é texto importante de O labirinto da saudade. O ensaio foi escrito em 1972, ou seja, no calor do IV centenário da primeira edição d'Os Lusíadas. O alerta de Eduardo Lourenço é azo para o começo desta conversa que reúne, entre nós, o mestre, o poeta, os irmãos Gama que o poeta inventou e outras vozes também bastante bem-vindas e ouvidas:

Camões não pertence a ninguém, mas na medida em que emprestou forma à existência e ao ser ideal da "pequena casa lusitana", e assim a subtraiu à informe existência histórica empírica, a ele pertencemos. O que convém é saber como. Camões e a sua obra, em particular os Lusíadas, não são uma realidade intemporal e de significação unívoca. Deslocá-los, arbitrariamente, da sua significação própria (...), para a falsa eternidade de um mito moral, histórico e ideológico cujas bases continuariam intocáveis, é celebrá-lo às avessas. (LOURENÇO, 1982, p. 164) 
Alerta feito, assimilo-o pretendendo avançar no projeto de pesquisa que desenvolvo desde pouco mais de um ano, "Problemas contemporâneos da poesia de Camões". Tento ler um Camões contemporâneo, não intemporal, posto que vivo em seu tempo e, por poder de viva leitura, no nosso - vivo porque corre muito sangue nas veias daqueles versos. Muitos são os sinais da sobrevida do grande poema camoniano, e um deles é o recente poema paraépico de Gonçalo Tavares, Uma viagem à Índia. No prefácio, Eduardo Lourenço escreve que "Os Lusíadas, a seu modo, também é já um texto de decepção, por conta da realidade" (LOURENÇO, 2010, p. 14). Lourenço é um leitor generoso, em vários níveis. Um deles é seu elenco de interesses, vário mas não pretensioso, permitindo que o pensador homenageado pelo colóquio que enseja este dossiê seja uma referência intelectual mas não um tudólogo, sedutora mas perigosa categoria, dado um famélico esboroamento de limites e de integrantes - nela agem desde um estudioso profundo como Umberto Eco até diletantes cheios de vaidade e fãs como Caetano Veloso. Longe disso, Lourenço, não obstante, escreve sobre muitos autores, entre eles jovens, como Tavares e a brasileira Luiza Nóbrega, que chamou a atenção do autor de Labirinto da saudade por seus estudos in progress acerca d'Os Lusíadas, mais especificamente do Baco camoniano. Diz o velho estudioso, partindo de texto de Luiza, que "OS Lusíadas são entre nós espelho insuperável e não ainda superado" (apud Nóbrega, 2013, contracapa). Essas duas afirmações recentes de Eduardo Lourenço ajudar-me-ão a urdir estas linhas que querem ler Camões com um auxílio mais que luxuoso, e elejo palavras-chave: do comentário sobre Tavares, extraio "decepção" e "realidade"; no sobre Luiza, "espelho" e "superação", dadas as ocorrências de "insuperável" e "não ainda superado".

Os Lusíadas, portanto, é deceptivo em virtude de um sentido de realidade. A primeira decepção ocorre já no título do poema: Os Lusíadas, não Os portugueses. Sem muita reflexão, posso adiantar minha suspeita de que o nome da obra quer-nos obrigar a nunca, no correr dos tempos mas também na contemporaneidade do século XVI, perder a dimensão mitológica que rege muito do éthos daqueles versos. Em resumo quase grosseiro, não é absurdo cogitar que a associação de Os Lusíadas a Luso, pai mítico da pátria, se mostre em diferença em relação à associação de Portugal a uma função mais militar e, no sentido menos criativo, histórica de Vasco da Gama - menos criativo entendo como incapaz de transcender uma série de imposições históricas.

Vindo da "realidade" (a palavra advém de Lourenço), há um conjunto de razões para a "decepção" (palavra também laurentina) camoniana. Vários leitores já enfrentaram a problemática narrativa do poema, dito, especialmente, por três vozes: a do narrador épico, a de Vasco da Gama e 
a do próprio Camões. Luiza Nóbrega, cujo trabalho enseja o comentário de Eduardo Lourenço que entende Os Lusíadas como "espelho insuperável e não ainda superado", entende que a única verdadeira identificação que a voz de Camões encontra no poema é com Baco, ainda que, digo eu, Vênus, em diversos momentos, encontre-se um bocado com certa mundivisão camoniana - sua feminina condução das ninfas, no Canto I, a salvar os portugueses literalmente com o peito, mais forte que ilustre, e, no VI, fazer semelhante ação com outra força, a de uma sedução amorosa e falada. De todo modo, é apenas Baco quem, dentro do poema, consegue ser personagem mitológica com consciência crítica histórica, dizendo coisas que poderiam ser ditas por Camões ou pelo Velho do Canto IV.

Decepciona Camões o próprio motivo da viagem, mercantil, e práticas mais militares que ilustradas levadas a cabo no percurso, o que motiva a furiosa crítica a Vasco da Gama que há no final do Canto V, logo após o capitão abandonar o posto de narrador do poema, assumido no Canto III. A estrofe-chave é a 97:

Enfim, não houve forte Capitão

Que não fosse também douto e ciente,

Da Lácia, Grega ou Bárbara nação,

Senão da Portuguesa tão-somente.

Sem vergonha o não digo, que a razão

De algum não ser por versos excelente

É não se ver prezado o verso e rima,

Porque quem não sabe arte, não na estima. (Lus, V, 97)

A crítica se estende a um Portugal incapaz de ler, do qual o Gama é apenas triste metonímia. Camões, metonímia da decepção, pois pretensa metonímia dos "barões assinalados" ( $L u s, \mathrm{I}, 1,1)$, é vítima de um processo muito real, pois histórico, e sua tarefa de ler a história será, portanto, ingloriosa e terá, necessariamente, que se revestir de um caráter revolucionário. Eduardo Lourenço tem toda a razão quando fala de realidade: Os Lusíadas, épico fincado numa viagem real que não é absorvida sem problemas pelo canto, dignifica-a pelo amor e pelo mito mas é recebido por "gente surda e endurecida" (Lus, X, 145, 4), incapaz de ouvir o que quer que seja já que "quem não sabe arte, não na estima". A revolução proposta pelo poema, "espelho insuperável e não ainda superado", é sempre adiada.

Jogo um pouco agora com a palavra "espelho", usada por Lourenço para se referir ao poema, ou melhor, à recepção do poema até hoje feita por certo Portugal que nele, ou em alguma leitura dele, baseia parte de sua autoi- 
magem. Sucessão de espelhos vindos da boca de Vasco da Gama é a história portuguesa, contada pelo militar com diversos requintes épicos, de que é exemplo o mito cristão que dá origem ao Estado, corporificado na Batalha de Ourique. História contada com muitos exemplos e gana de exemplaridade, espelhante do caráter português segundo um sentido de realidade diacronicamente estabelecido - era o caso de considerar, agora, a sincronia terrível que o poema às vezes sugere, muitas vezes afirma, mas isso fica, por razões de espaço e tempo, para outra ocasião. Na diacronia do Gama, o espelho se manifesta em ocasiões como os versos finais das estâncias 138 e 139 do Canto III; logo após os elogios ao reinado do "justo e duro Pedro" (Lus, III, 138,1 ), apelidado de Pedro, o Cru, os dois versos desabonam D. Fernando, personagem que se notabilizou não por qualidades gerenciais ou militares, mas por ter amado tanto que chegou às raias da loucura e da violência - o rapto de Lianor não poderia ser bem visto por alguém como Vasco da Gama.

Os versos: "Que um fraco Rei faz fraca a forte gente" (Lus, III, 138, 8) e "Que um baxo amor os fortes enfraquece" (Lus, III, 139, 8). Os espelhos: Inês, inocente, é louvada pelo duro militar, e Fernando, estrofes depois, é atacado; o povo, inocente, é enfraquecido pelo torpe rei, ainda que Fernando, estrofes depois, seja perdoado - Vasco da Gama, na verdade, pode, sim, ver com alguma solidariedade o amor e suas consequências, pois, no poema, ele é mais que personagem, ele é conjunto de diversas funções. Por isso, incoerente como ninguém mais, o Gama funciona de maneiras diversas, inclusive fazendo referências à mitologia e expondo a umbrosa face de um Portugal que Camões viu agarrado a "uma austera, apagada e vil tristeza" (Lus, X, 145, 8). Falar sobre essas coisas exige-me expressar uma fundamental divergência que tenho em relação a um aspecto da leitura que Os Lusíadas recebe de Eduardo Lourenço: o crítico não logrou saltar da armadilha que vê o poema como uma máquina de guerra. A razão disso talvez seja a maior aderência que Lourenço tem em relação a Pessoa, que, por estratégicas razões, atacou Camões o quanto pôde. Mas o que herdo do leitor atento é muito mais que o que deixo pelo caminho, o que fica provado neste texto.

O outro momento do poema em que a história de Portugal é revista está no Canto VIII, quando Paulo da Gama exibe as bandeiras aos visitantes indianos; nelas, dentro de lusa embarcação, ocorrências importantes da construção nacional. São também espécies de espelhos o que Paulo da Gama vê e comenta, a fim de mostrar seu legado a representantes do estranho povo que habita Calecute. E esses espelhos são, ao contrário dos do irmão de Paulo, fatos artísticos, pinturas, "Feitos dos homens que, em retrato breve,/ A muda poesia ali descreve." (Lus, VII, 76, 7-8), como se lê ainda no Canto VII. Grafei há pouco "lusa embarcação" porque é Luso quem está retratado na primeira das bandeiras, e a personagem mitológica, filho e/ou compa- 
nheiro de Baco, origina o nome do poema porque, de acordo com Paulo, é efetiva origem do nome coletivo do povo viajante, pois no "ninho Hispano" (Lus, VIII, 3, 3) "quis dar aos já cansados ossos/ Eterna sepultura, e nome aos nossos." (Lus, VIII, 3, 7-8)

Costuma instigar alguns leitores o fato de ser Paulo da Gama o narrador de momento tão nuclear do poema, situado entre o mais intenso desabafo do poeta e o sequestro de Vasco da Gama. Na economia da diegese, só podia ser Paulo o apresentador das bandeiras, posto que seu irmão estava em terra, tendo sido recebido pelo Samorim indiano em seu magnífico palácio. Mas não é só: a tarefa de Paulo é, à partida, ficcional, posto que as imensas bandeiras descritas existem apenas no poema, enquanto a de Vasco foi um relato histórico, ficcional apenas quando a função do comandante exigiu diç̧ão com ardência extra. Na lida do irmão mais poderoso, uma notícia mitologicamente dúbia a inaugurar a descrição da gente lusitana - "Esta foi Lusitânia, derivada/ De Luso ou Lisa, que de Baco antigo/ Filhos foram, parece, ou companheiros,/ E nela antam os íncolas primeiros." (Lus, III, 21, 5-8) - e, depois, história, basicamente. Na do outro, uma atenção aguda a Luso e a afirmação, sem qualquer "parece", de que a personagem "foi seu companheiro", ou seja, de Baco, "e filho amado" (Lus, VIII, 4, 4). Após Luso, claro, Ulisses, e só depois Viriato.

Realidade, disse Eduardo Lourenço, coisa que interessa, para bem ou para mal, a Camões. A realidade do poeta cuja pena tem sob si um épico está cheia de figuras históricas que ocupam lugar não cimeiro, posto que costuma ser, por exemplo, dos reis. Sem perder de vista que são os reis os condutores do relato de Vasco da Gama, salta-me que o relato de Paulo da Gama seja centrado em gente, por assim dizer, de empreitadas mais diretas, corpo a corpo - exemplos não faltam, desde Sertório até Dom Pedro de Meneses, desde Martim Lopes até Dom Fuas Roupinho, passando pelo incontornável e ambivalente Nunálvares Pereira, hoje santo, sublinhado por Paulo justamente por sua fé, enquanto Vasco, ao falar do Condestável, realçara sua coragem e sua força.

Pensar em história, histórias e tratamento de personagens históricas n'OS Lusíadas faz-me voltar a "Camões no presente", onde leio: "o patriotismo de Camões salvaguardou aquele mínimo de lucidez (...) sem o qual nos pareceria (...) ridículo ou odioso. Camões glorifica e exalta no 'peito ilustre lusitano' valores ou atitudes que ele crê universalmente válidos" (LOURENÇO, 1982, p. 169). Se articularmos a noção laurentina de "mínimo de lucidez" às duas vozes mestras da abordagem histórica no poema, as dos irmãos Gama, poderemos notar um investimento na própria contradição, pois ambos os parentes fundam-se em lucidezes próprias, discutíveis, por certo, mas argumentadas; aprendi o que disse inclusive com Lourenço, 
pois o fecho de "Camões e a visão neoplatônica do mundo", texto de Poesia e metafísica, é: "não se devem procurar na obra de Camões ideias cerzidas na evidência e na linearidade" (Lourenço, 1983, p. 66). Não penso apenas na contradição, marca indelével do discurso camoniano, mas também na generosa distribuição na mesa que Camões empreende de distintas falas, construindo um panorama dialogal e polifônico generoso a ponto de, pelas contradições, construírem-se algumas aporias e serem sugeridos terceiros termos, ainda que não-lineares - e terceiros justamente porque não-lineares.

Nesse sentido, aponto um comentário de José Augusto Cardoso Bernardes sobre uma fundamental diferença entre o Lourenço leitor de Camões e o grande camonista que foi António José Saraiva. Em ensaio intitulado "Eduardo Lourenço, Camões e o poder da literatura", afirma Bernardes que "Saraiva havia estatuído a existência de um poeta dialéctico", o que, no caso d'Os Lusíadas, se manifesta especialmente na oscilação "entre a glorificação da viagem e a sua crítica, entre a ética de cavaleiro e a consciência pequeno-burguesa”. Segue Bernardes:

Perante esta tese, que tanto ficava a dever aos modelos hegelianos e marxistas, o que tinha Lourenço a opor? Essencialmente isto: que, mais do que dialéctico, Camões era contraditório e dilacerado. Era-o nas vozes que instituía como nas ideias veiculadas; era-o enquanto expressão de um tempo (também ele polimorfo) mas era-o sobretudo sob o ponto de vista intrinsecamente humano. (BERNARDES, 2009, p. 123)

Não é tanto, segundo Bernardes, um simples, ou nem tão simples, caso de dialética, como supunha Saraiva. É, ao olhar de Eduardo Lourenço, um caso de contradição, traço reforçado por Camões ter instituído, como indica o citado fragmento, muitas vozes. Abraço agora mais a contradição que a dialética, retorno às palavras de Lourenço que me guiam, "decepção" e "espelho", sigo lendo Camões com o mestre e expresso o que mais me interessa no pormenor a que me estou dedicando: existe um espelhamento entre Paulo da Gama e Camões, cuja tangência mais evidente é o valor que ambos dão à obra de arte. Diversas estâncias após ter começado sua descrição, Paulo da Gama diz:

Outros muitos verias, que os pintores

Aqui também por certo pintariam;

Mas falta-lhe pincel, faltam-lhe cores: 
Honra, prémio, favor, que as artes criam:

Culpa dos viciosos sucessores,

Que degeneram, certo, e se desviam

Do lustre e do valor dos seus passados,

Em gostos e vaidades atolados.

Aqueles pais ilustres que já deram

Princípio à gèração que deles pende,

Pela virtude muito antão fizeram,

E por deixar a casa que descende.

Cegos, que, dos trabalhos que tiveram,

Se alta fama e rumor deles se estende,

Escuros deixam sempre seus menores,

Com lhe deixar descansos corruptores.

Outros também há grandes e abastados,

Sem nenhum tronco ilustre donde venham;

Culpa de Reis, que às vezes a privados

Dão mais que a mil, que esforço e valor tenham.

Estes os seus não querem ver pintados,

Crendo que cores vãs lhe não convenham,

E, como a seu contrairo natural,

À pintura que fala querem mal. (Lus, VII, 39, 40, 41)

Nisso que é uma exposição em vários sentidos, pois exibição de arte e de personagens históricos, Paulo da Gama, personagem cujo estatuto é, na viagem, subordinado ao do irmão mais poderoso, lamenta "não se ver prezado o verso e rima,/ Porque quem não sabe arte, não na estima"; já que Vasco é metonímico alvo do final do Canto V, jamais poderia ser ele a mostrar as bandeiras ao indiano. Além do mais, a crítica é enfática ao poder, o que não poderia sair da boca do futuro, no tempo do poema, Vice-Rei da Índia. Pelo contrário, pôde ser feita por alguém cuja fama é mais semelhante à dos homens menos poderosos que ocupam as bandeiras que aos reis que ocuparam o relato de Vasco da Gama - nesse sentido, a subalternidade poética de Camões tem como contraface o imenso poder que o poeta se confere artisticamente, poder simbólico que deveria ter consequências práticas, até políticas. Por isso inclusive, Lourenço está certíssimo ao chamar Os Lusía- 
das de "texto de decepção", e sua percepção das muitas vozes do poema conduz-me a pensar em alteridade e a lamentar que o autor de Mitologia da saudade não tenha prestado muita atenção em Paulo da Gama - mas não faz mal, pois ele me ajuda a prestar.

Uma das falas deceptivas do poema é a de Paulo, fala cheia de valores camonianos, que critica os poderosos e os herdeiros de homens valorosos; ambos são sabotadores da arte e causadores de um tipo de desconcerto do mundo que é o divórcio entre arte e realidade, ou entre artista e poder - poder, sobretudo, de comunicação. $O$ espelho também se faz entre Paulo e o narrador: o irmão de Vasco da Gama chama a poesia de "pintura que fala", enquanto o narrador abriu o quiasmo completado pelo navegador com a expressão "a muda poesia". Os mercantis e guerreiros poderosos, estes "querem mal à arte", e a consequência disso é a "gente surda e endurecida" preocupada com o dinheiro demonizado no fim do Canto VIII, justo o que tem em seu começo a fala de Paulo da Gama - entre as indecências do vil metal está depravar "às vezes as ciências" (Lus, VIII, 98, 7). Essa percepção se liga, de acordo com Lourenço, ao modo como Camões, homem de muitos tempos mas também do seu, entendia literatura; leio em "Camões e o tempo ou a razão oscilante":

O tempo de Camões foi, antes de mais, aquele em que a obra teve de se assumir como realidade literária, aquele em que os autores começam a viver de olhos abertos a aventura cega, ainda inacabada, da "Literatura". o discurso poético já não se esgota na sua função objectiva ou subjectivamente útil - de ordem moral ou religiosa -, mas dirige-se, por assim dizer, a um auditório impessoal e intemporal. (LOURENÇO, 1983, p. 34)

Esse auditório é surdo ao poema, e ser surdo ao poema é ser surdo ao que Lourenço chama de "aventura cega" e "inacabada". Em estatuto semelhante ao literário, Camões enxerga a pintura, e veria outras linguagens artísticas se tivesse tido intimidade com elas - teve-o com o teatro, e produziu autos de pós-vicentina importância; imagino um Camões que pudesse ver cinema, tendo ele produzido, em seu épico, cenas de agudo poder cinematográfico, de que exemplo insuperável é certo momento do Canto VI: após Baco convencer Netuno a destruir a esquadra, com o leitor sabendo da vindoura tormenta, pois os ventos estão preparados, a ação é suspensa para um período de quietude na embarcação onde está Veloso; durante várias estrofes, o autoconfiante militar conta o episódio dos Doze de Inglaterra. A suspensão da narrativa báquica-netunina para o caso pleno de amor cortês encontra um leitor que conhece o futuro próximo, enquanto as personagens 
o ignoram: suspense cinematográfico, em que abundam imagens e se celebra uma metonímia de feminino que não posso desenvolver agora, mas que, em futuro divisável, voltarei a recolher.

Por isso, se o grande professor ora nonagenário afirmou que o "discurso poético", no tempo de Camões, "já não se esgota na sua função objectiva ou subjectivamente útil - de ordem moral ou religiosa", e como eu suponho que isso, em casos como o camoniano, se dá de maneira especial, em virtude da modernidade que neles se descortina, devo pensar que a arte passa então a ter o direito a ser ética, não moral. Penso na distinção feita por Gilles Deleuze lendo Spinoza, e lembro-me da grande relevância que tinha, para Camões, o contato do sujeito com a realidade. Um fragmento de Gilles Deleuze que me interessa cada vez mais, e ainda mais agora, quando leio Camões com Eduardo Lourenço, diz que

(...) a Ética, isto é, uma tipologia dos modos de existência imanentes, substitui a Moral, a qual relaciona sempre a existência a valores transcendentes. A moral é o julgamento de Deus, o sistema de Julgamento. Mas a Ética desarticula o sistema de julgamento. A oposição dos valores (Bem/Mal) é substituída pela diferença qualitativa dos modos de existência (bom/mau). (...). Ora, basta não compreender para moralizar. (DELEUZE, 2002, p. 29)

Camões, em resumo, é o tipo de artista aberto à modificação de seus paradigmas de acordo com a experiência, que é, exemplos não faltam (o Velho é apenas um deles), caminho para a construção do conhecimento. Ao ler Deleuze afirmar que "basta não compreender para moralizar", vêm-me imediatamente à lembrança os versos finais do bacanal do Canto IX: "Milhor é exprimentá-lo que julgá-lo/ Mas julgue-o quem não pode exprimentá-lo" (Lus, IX, 83, 7-8). Para além da defesa da liberdade erótica como índice, renascentista inclusive, de solaridade e celebração humana, o verso constata que se só compreende a experiência humana através da experiência. Tautológica conclusão, mas resultado do que Deleuze chama de desarticulação do sistema de julgamento divino, o que, no caso camoniano e em outros do mesmo período histórico, Lourenço entende como superação da função moral ou religiosa da literatura.

São muitos os exemplos de uma construção ética em Camões. Em texto intitulado "Facetas de uma ética revolucionária em Camões", dedico-me a refletir acerca de por que as estâncias finais d'Os Lusíadas são um flagrante anticlímax, e no que poderá haver de ético nesse procedimento. Em certo momento conclusivo, digo que, "se o encerramento do poema (...) é chato" - parto, no ensaio, da opinião de um conhecido professor de literatura portuguesa -, "é-o em virtude de um compromisso, não com as musas (as musas lá estão, e sempre estarão (...)), nem com o mito (o mito lá está, e 
sempre estará, contribuindo para a construção de um discurso rebelde), mas com a mudança concreta de uma realidade" (MAFFEI, 2011/ 12, p. 23). Uma consequência política é levada a cabo a partir da ética premissa contestatória n'OS Lusíadas, construindo diversos momentos de contestação furiosa contra o caráter mercantil e guerreiro de um Portugal deficiente - "surda" a "gente", inapta para receber o canto, incapaz de relações mesmo no nível mais imediato da recepção auditiva de um construto simbólico. Como bem disse Lourenço, não se trata de moral, mas de tocar um "auditório impessoal e intemporal" forçando-o a perceber-se histórico, seja em que construção subjetiva, seja em que tempo.

Isso me lembra uma característica por vezes subestimada d'Os Lusíadas, que é a abertura ao outro, configurada muitas vezes, mesmo que não todas, generosamente. Isso é mais do que evidente em casos como o do Adamastor e o de Inês, cenas em que um Vasco da Gama posto em função de magnânimo repórter possibilita ao leitor contato direto com dramas alheios a impérios e trocas mercantis, ainda que o Estado tenha matado Inês. Mais sutis são falas como a de Monçaide, o mouro trilíngue que ocupa fronteiriço papel no Canto VII - ele fala dos portugueses aos indianos, mas primeiro dos indianos aos portugueses, e, aquando da confusa partida das naus, embarca cristianizado para voltar ao ocidente. Monçaide encerra sua apresentação do novo outro (houve muitos às margens de Atlântico e Índico) em estância curiosa:

Gerais são as mulheres, mas apenas

Para os da geração de seus maridos:

Ditosa condição, ditosa gente,

Que não são de ciúmes ofendidos!

Estes e outros costumes variamente

São pelos malabares admitidos.

A terra é grossa em trato, em tudo aquilo

Que as ondas podem dar da China ao Nilo. (Lus, VII, 41)

Tenho em mente o "auditório impessoal" referido por Lourenço, e vejo Monçaide fazer um discurso, na dinâmica da exegese, a auditório bastante localizado, composto por grupo relativamente coeso e bastante interessado. O poema faz com que essa fala se espalhe pelo universo, e atinja vários tempos e lide com várias morais. A fala não é de Camões, nem do narrador épico, e é necessário sempre saber, n'Os Lusíadas, quem está falando. O mouro, justo no poema que dá coesão e modernidade a nosso idioma, fala, na "língua de Castela" (Lus, VII, 29, 2), ou seja, ainda não em 
português, que "Gerais são as mulheres, mas apenas/ Para os da geração de seus maridos:/ Ditosa condição, ditosa gente,/ Que não são de ciúmes ofendidos!". Não foi Camões enquanto tal quem celebrou essa relativa liberdade sexual, talvez nem o pudesse fazer, posto que, dado a uma constante solidariedade ao feminino, nosso poeta poderia ver nisso um excessivo privilégio do homem. Por outro lado, há uma liberdade, ainda que relativa, no trato com o corpo, e as mulheres podem conhecer diversos parceiros. Nesse sentido, lembro-me dos versos "Milhor é exprimentá-lo que julgá-lo/ Mas julgue-o quem não pode exprimentá-lo", e lembro-me também de que as ninfas que receberam os navegadores tinham, no plano mitológico, seus respectivos parceiros. Seriam elas "gerais"? Se o forem, serão somente para criaturas muito diversas de seus maridos, pois, se os maridos são deuses, os maridos novos são humanos.

Mas os poderosos são mercantis e guerreiros, e mercantil e guerreira é também a viagem, que levou Paulo, historicamente, à morte: ao contrário de seu irmão, que veio a ter farto poder na Índia (o filho de Vasco da Gama, a propósito, também o teria), Paulo da Gama morreu enquanto a esquadra regressava a Lisboa, tanto que teve de ser sepultado nos Açores. Penso ser essa a tangência mais instigante entre Camões e Paulo da Gama: enquanto o comandante da nau São Rafael sucumbe (aliás, a própria nau, por assim dizer, morreu na viagem de volta), Camões performativa sua morte no poema. É importante observar que o poeta se morre exatamente no momento em que começa a exposição de Paulo da Gama, e a analogia que marca o fim do degredado cantor ocorre na estância 79 do Canto VII:

Olhai que há tanto tempo que, cantando

O vosso Tejo e os vossos Lusitanos,

A Fortuna me traz peregrinando,

Novos trabalhos vendo e novos danos:

Agora o mar, agora exprimentando

Os perigos Mavórcios inumanos,

Qual Cánace, que à morte se condena.

Nua mão sempre a espada e noutra a pena; (Lus, VII, 79)

A problemática nesses versos não desagua na conjunção poeta-soldado que se vê, por exemplo, na estância 155 do Canto X, nos versos "Pera servir-vos, braço às armas feito;/ Pera cantar-vos, mente às Musas dada;" (Lus, X, 155, 1,2). Perto do fim do Canto VII, a pena e a espada são bem diferentes, pois o poeta, além do lamento por um canto dado aos lusitanos mas por eles não ouvido, atinge o paroxismo de sua solidão amante comparando- 
-se com Cánace. Filha de Éolo e Enarete, esta personagem mitológica, segundo Ovídio, foi obrigada pelo pai a matar-se, pois tinha cometido incesto com Macareu, um de seus irmãos. Enquanto comete o suicídio forçado, Cánace escreve ao irmão uma carta, misto de texto amoroso e triste despedida. A estrofe é cheia de referências mitológicas, desde as novas Ninfas nacionais, alocutários expressos na 78, passando pelos lusitanos, por Marte e chegando a Cánace. Fica sedutor cogitar a hipótese de o poeta estar sendo morto por sua Pátria, que é quem lhe dá a espada de soldado, pois a Cánace, quem deu a espada de sua morte foi Éolo, seu pai. Portanto, o final da estrofe 78 é o mais veemente canto de morte feito por Camões, que aceita seu destino como um herói de espírito bastante mais trágico que épico.

É necessário voltar à 78 , pois o começo do lamento camoniano se dá quando o narrador já começa a apresentar a exposição de Paulo da Gama. Já começada a indicação de Luso, que "Um ramo na mão tinha", Camões toma a fala para, no meio de um verso, dizer de si "cego", "insano" e "temerário", e iniciar o desabafo cujo clímax é sua morte forçada: "Um ramo na mão tinha... Mas, ó cego,/ Eu, que cometo, insano e temerário,/ Sem vós, Ninfas do Tejo e do Mondego,/ Por caminho tão árduo, longo e vário!" (Lus, VII, 78, 1-4). No ensaio já citado, José Augusto Cardoso Bernardes entende que Eduardo Lourenço vê, na épica camoniana, o poeta proceder a uma "invenção heroica de si mesmo, dentro da linha humanista e renascentista da autoimortalização", algo que "já Sena (com quem Lourenço mantém algumas zonas de intersecção no que toca ao camonismo, não de método mas de atitude) sublinhara" (BERNARDES, 2009, p. 127).

Percebo essa invenção heroica como gesto ficcional, sendo Camões consciente, como apontam algumas práticas mesmo de sua lírica, do que seja fingimento no universo da poesia - exemplo disso é afirmar "Eu cantarei de Amor tão docemente" após ter dito famoso quarteto de outro soneto: "Porém, temendo Amor que aviso desse/ Minha escritura a algum juízo isento,/ Escureceu-me o engenho co tormento/ Para que seus enganos não dissesse" (CAMÕES, 2005, p. 125). Digo ficcional podendo dizer metonímico, posto que, ao se fazer herói, Camões não deixa de se pretender representante da coletividade dos "barões assinalados" (Lus, I, 1, 1), e, ao se autoimortalizar, fá-lo dentro do Canto, reclamando, no fundo, a imortalização do próprio canto, mais que a do poeta. No limite, talvez seja possível ver uma hipótese de prática sacrificial no poema, que ficciona a morte do poeta em defesa da sobrevida do texto, ou seja, a autoimortalização depende da morte.

Nesse sentido, Paulo da Gama também experimenta uma espécie de sacrifício, certamente involuntário se pensarmos em história, mas, na sua ficcionalização dentro d'Os Lusíadas, de grande poder simbólico, especialmente por duas razões. Em primeiro lugar, os heróis expostos pelo irmão de 
Vasco, secundários em relação aos reis, experimentaram mortes poderosamente memoráveis; além disso, morto (e sua morte sequer é apontada pelo narrador épico), Paulo não apenas se infiltra nesse rol, mas permite que se ressalte, amante das artes que é, ao menos no poema, o que há de estético nas bandeiras como constructos artísticos. Ambos, o poeta e Paulo da Gama, cultivam a premiação de outros heróis, e ambos, cada um a seu heroico modo, são privados em vida do prêmio por seus trabalhos. Aliás, Paulo não é um dos navegadores nomeados no episódio da Ilha do Amor, ao contrário de Veloso, Lionardo e do próprio Vasco da Gama, que do amor vai ao banquete, do banquete a um conhecimento, sensual, portanto, da Máquina do Mundo.

Bernardes, em seu texto, indica a afinidade, ainda que não de método, entre os camonismos de Eduardo Lourenço e Jorge de Sena. Foi justamente Eduardo Lourenço quem escreveu uma estimulada resenha, no jornal $O$ Comércio do Porto, recebendo o longo estudo seniano Uma canção de Camóes - o livro é de 1965, a resenha, de 1967, mais precisamente de 05 de dezembro de 1967, e sua publicação, portanto, aniversaria curiosamente no dia em que este texto foi lido oralmente no colóquio. Ressaltando sempre o caráter estruturalista do estudo, Lourenço, mais de dez anos antes da publicação de $O$ labirinto da saudade, logo aproximadamente uma década antes de afirmar, peremptória e elegantemente que "Camões não pertence a ninguém", celebra um leitor camoniano que procura uma efetiva leitura do grande poeta, que por práticas assim pode voltar a ser literatura, ele que se fez poema em ficcional sacrifício. Por isso, comentando uma obra que "deseja pôr fim a uma tradição de crítica impressionista” (LOURENÇO, 1967, p. 4), Lourenço acaba por se filiar à perspectiva de Sena, segundo a qual Camões é um poeta mal lido - ou, como dirá o autor de Heterodoxias, não raro é celebrado "às avessas".

Na "Nótula a uma 'Canção de Camões'”, Eduardo Lourenço diz que "a análise estrutural que Jorge de Sena consagra à poesia camoniana (...) penetra mais fundo na realidade mesma dessa poesia e se permite descortinar nela aspectos que outros projetos críticos são incapazes de ver" (LOURENÇO, 1967, p. 4). Por Sena, enfim, a obra de Camóes é lida e tida como tal, o que me faz chegar a um ensaio de Portugal como destino, "Romantismo, Camões e a saudade", no qual o pensador que enseja nosso encontro diz coisas muito pertinentes acerca da recepção que Camões recebeu, no país que tentou inventar e na língua que inventou, no século XIX. Lourenço investiga, antes de tudo, as razões por que o Romantismo foi tão permeável a Camões: 
Chateaubriand, Schlegel ou Ludwig Tieck foram sensíveis (...) à presença, estranha numa epopeia de perfil clássico, do poeta, com a sua voz grave de herói extenuado, com a sua indignação perante a arbitrariedade da sociedade e dos poderosos, com a sua angústia, tão moderna, perante o desconcerto da História e do Tempo (...) (LOURENÇO, 1999a, p. 56)

Lourenço aponta para a condição complexa do poema camoniano, eivado de muitos componentes de diversas origens e, sem perverter as "cores originais", construtor de uma poderosa sintaxe aberta ao novo, moderna na "angústia" mas também, por exemplo, em outra tensa sintaxe, a de vozes, que funda uma polifonia plena de atritos. A arquitetura clássica, com seus heróis e deuses, acolhe um herói sobre todos, o próprio cantor, "extenuado" e morredouro, que é, por outro lado, herói sob todos, pois entende que sobre seu sacrifício deve-se erguer uma coletividade por ele premiada. Além disso, se, diz Lourenço pensando no Almeida Garrett que escreveu Camóes, poema fundador do Romantismo português, os "românticos não viajam realmente para o passado, antes trazem o passado para o presente" (LOURENÇO, 1999a, p. 59), talvez seja porque Camões, em imensos momentos de sua poesia, inclusive a lírica, trouxe o futuro para seu tempo, antecipando traços que, como bem disse o autor de Tempo e poesia, serão românticos. Outros podem ser elencados, por exemplo, e acima de tudo, a consciência de que amor é componente fundamental do humano, e que existe uma forte correspondência entre sentimento amoroso e sentido de mudança, inclusive uma que possa alterar a realidade coletiva. Nome adequado a isso é política, sem a menor dúvida.

Após referir-se a diversos abraços, inclusive de urso, que Camões recebeu no século XIX - os primeiros republicanos, por exemplo, adotando-o como aliado à revelia e Antero de Quental considerando Os Lusíadas também culpado da decadência portuguesa -, Eduardo Lourenço chega, afinal, a um leitor camoniano com quem se afinará num ponto central: "OS Lusíadas, mesmo em sua época, não era para Oliveira Martins um livro de glória, um livro verdadeiramente solar, mas antes o memorial de um povo em declínio e prometido à morte. Uma obra assim não pode salvar-nos de nada" (LOURENÇO, 1999a, p. 61), pois é, como diz uma das afirmações-chave para esta fala, presente no prefácio a Uma viagem à Índia, "texto de decepção". o grande contributo que o olhar de Oliveira Martins deu aos seus contemporâneos e aos futuros leitores de Camões, assim Lourenço enuncia:

A leitura de Oliveira Martins teve um efeito inesperado. Não podíamos continuar a ter por anjo tutelar um poeta tão profundamente ancorado na espessura da História e do Mundo, um poeta épico, 
mesmo na versão elegíaca do Romantismo. No final do século XIX e no princípio do século XX, a classe letrada de Portugal está imersa num agudo sentimento de irrealidade: Mundo, História, Eu, existência coletiva nacional são vividos e descritos como realidades fantasmagóricas recortadas numa espécie de névoa. $\mathrm{O}$ imaginário cultural instala-se voluptuosamente no puro sonho. (LOURENÇO, 1999a, p. 62)

Como receber um épico como guia em momento de decadência? Eduardo Lourenço, em "Camões no presente", entende a posição de Teófilo Braga, cuja comemoração no primeiro 10 de junho teve a virtude de celebrar o amor da Pátria presente no poema, entendendo, entre outras coisas, que o povo português, majoritariamente, não sabia ler. Mas Oliveira Martins, sem pôr de lado o texto, é quem se nega à irrealidade e a perigosas fantasmagorias e propõe uma mirada que não se encontra tão distante da proposta por Cesário Verde n' "O sentimento dum Ocidental”, obra marco de uma tentativa que, pela via da negatividade, em nada negadora, aliás, do amor por Camões, pelo contrário, tenta polemizar o gigantismo do mito e recuperar do poeta alguns aspectos bastante sombrios - o cansaço, a crítica, a solidão. Cesário sugere em seu poema escrito para o primeiro Dia de Camões que o homenageado de data tão funérea, data da morte passada do poeta e metonímia da morte presente do país, não fugiu, como também enxergou Oliveira Martins, do mundo e da história, tendo defrontado fantasmas bastante concretos. É por isso que sonho, para Cesário Verde, é quimera irrealizável, evasão em nada romântica nem utópica, delírio, abertura à dor.

"Camões no presente", publicado pela primeira vez, ressalto, em 1972, no calor do quarto centenário da edição do poema, já citara Oliveira Martins, desta vez em parceria com Antero: para os dois gigantes, afirma Lourenço, "a única homenagem insuspeita que a Camões se deve é a leitura (...) do seu livro imortal, o que supõe (...) a criação de uma Cultura onde o Poema possa ser vida efectiva do espírito e não referência ritual e fonte oca de um patriotismo obtuso e interesseiro." (LOURENÇO, 1982, p. 166). Isso, dito quando foi dito, teve uma força que visava atingir um poder fascista que, então, andava aos bordos sobre as pernas. Agora, a afirmação tem outra força, ainda pujante, pois não sei se a "Cultura onde o Poema" pode ser o que Lourenço chama de "vida efectiva do espírito" foi inventada. Afirmo isso porque, há aproximadamente vinte anos, na altura em que o século sinalizava que quereria mudar de número, Lourenço escreveu alguns textos espantados. Ocorrem-me agora dois deles; um, lido pela primeira vez no Rio de Janeiro, em 1992, intitulado "Dois fins de século", que aponta para as diferenças e semelhanças entre o fim do século XIX e o fim do XX. Mas cito outro, que guarda uma afirmação que este texto que já começa a se concluir 
não poderia deixar de convocar. O fragmento diz respeito a dois poetas bastante machucados em seus respectivos presentes e futuros:

(...) excesso de passado (...) não resolve nada (...), fazendo-nos crer que em pleno triunfo da mundialização cultural nós já a tínhamos antecipado e que não há nada que possa surpreender-nos quando somos ao mesmo tempo o país de Camões e de Pessoa. Deste último sobretudo, que já dissolvera o universalismo particularista de Camões no universalismo das puras diferenças onde todos somos tudo e ninguém. (LOURENÇO, 1999b, p. 107)

O texto, datado de 1996, intitula-se "Tempo português". Camões e Pessoa, donos de universalismos particularistas, foram frequentemente transformados em outras coisas que não poetas. Para além de haver, ao menos desde Jorge de Sena, grandes leitores camonianos, e os autores que mereceram os comentários laurentinos que me ajudaram nesta reflexão são exemplos vivos disso, marco no comentário a importância de que se leia os poeta como tais, como Oliveira Martins percebeu com argúcia no caso de Camões. Por isso, volto à primeira citação que fiz a Eduardo Lourenço neste texto:

Camões não pertence a ninguém, mas na medida em que emprestou forma à existência e ao ser ideal da "pequena casa lusitana", e assim a subtraiu à informe existência histórica empírica, a ele pertencemos. O que convém é saber como. Camões e a sua obra, em particular Os Lusíadas, não são uma realidade intemporal e de significação unívoca. Deslocá-los, arbitrariamente, da sua significação própria (...), para a falsa eternidade de um mito moral, histórico e ideológico cujas bases continuariam intocáveis, é celebrá-lo às avessas.

É sempre em deslocamento que se fazem as leituras, pois, como diz, em Tempo e poesia, o mestre a quem desejamos muitas felicidades e muitos anos de vida, "a escrita é um risco total. De uma maneira geral ninguém a lerá como o seu autor a concebeu" (LOURENÇO, 2003, p. 87). Cabe-nos fazer o melhor, porque mais ético e mais responsável, deslocamento de Camões, e a direção desse movimento que parte de um presente múltiplo e agudo, inegavelmente mais crônico que cronológico, é o futuro. 
maffei, L. Ler Camões com Eduardo Lourenço ou Camões no futuro com Paulo da Gama...

\section{REFERÊNCIAS}

BERNARDES, José Augusto Cardoso. Eduardo Lourenço, Camões e o poder da Literatura. Colóquio/Letras, Lisboa: Fundação Calouste Gulbenkian, n.171, p. 119-132, maio 2009.

CAMÕES, Luís de. Os Lusíadas. Edição de Emanuel Paulo Ramos. Porto: Porto Editora, 1978.

DELEUZE, Gilles. Espinoza - filosofia prática. Tradução de Daniel Lins e Fabien Pascoal Lins. São Paulo: Escuta, 2002.

LOURENÇO, Eduardo. Camões e a visão neoplatônica do mundo. In: . Poesia e metafisica

- Camóes, Antero, Pessoa. Lisboa: Sá da Costa, 1983. p. 51-67 . Camões e o tempo ou a razão oscilante. In: . Poesia e metafisica-Camões, Antero, Pessoa. Op. cit. p. 31-50.

Camões no presente. In: .o labirinto da saudade - psicanálise mítica do destino português. 2. ed. Lisboa: Dom Quixote, 1982.

. Nótula a uma "Canção de Camões". O Comércio do Porto, Porto, 5 dez. 1967, p. 14.

. Romantismo, Camões e a saudade. In: . Mitologia da saudade. São Paulo: Companhia das Letras, 1999a. p. 54-64. Tempo e poesia. 2. ed. Lisboa: Gradiva, 2003. Tempo português. In: . A nau de Ícaro seguido de Imagem e miragem da lusofonia.

2. ed. Lisboa: Gradiva, 1999b. p. 105-110.

. Uma viagem ao coração do caos. In. TAVARES, Gonçalo M. Uma viagem à Índia. Lisboa: Caminho, 2010. p. 9-20.

MAFFEI, Luis. Facetas de uma ética revolucionária em Camões. Relâmpago - revista de poesia, Lisboa: Fundação Luís Miguel Nava, 29/30, 2011/ 2012.

NÓBREGA, Luiza. No reino da água o rei do vinho - submersão dionisíaca e transfiguração trágico-lírica d'Os Lusíadas. Natal: EDUFRN, 2013.

Submetido em: 08/04/2014

Aceito em: 05/09/2014 